\title{
Development of Guidance and Counseling Services to Improve Student Questioning Skill in Classical Format Learning
}

\author{
Nurfarida Deliani $^{1^{*}}$, Prayitno ${ }^{2}$, A. Muri Yusuf ${ }^{2}$, Jamaris Jamna ${ }^{2}$ \\ ${ }^{1}$ Student of Education Science, Universitas Negeri Padang, Padang, Indonesia \\ ${ }^{2}$ Lecture of Faculty of Education Science, Universitas Negeri Padang, Padang, Indonesia \\ *Corresponding author. Email: deliani.nurfarida@yahoo.com
}

\begin{abstract}
Students poor educational questioning skills can have adverse negative effects on the learning process and must be handled by the Counsellor appropriately. This study aims to develop guidance and counselling service that would assist in enhancing students questioning skills in classical format learning. The research method used is the R and D (Research and Development) with the development pattern of ADDIE (Analysis, Design, Development, Implementation, and Evaluation). The model developed is in the form of a Guidebook and Companion book that would guide and counsel students in how to ameliorate their questioning skills. The research subjects consisted of experts for model feasibility testing, counsellors to assess the use of the model, and students to test for effectiveness. Data was obtained through questionnaires and interview guidelines. The data gathered was processed using the Concordance Kendall W and Wilcoxon Signed Rank Test. The results showed that the feasibility and suitability of the model were in a category that was very feasible and usable. The effectiveness of students before and after being given guidance and counselling services, were tested to determine student skills significantly. The results show that the guidance and counselling services is effective to improve students questioning skills in classical learning.
\end{abstract}

\section{Keywords: Guidance and counseling services, student questioning skill}

\section{INTRODUCTION}

Questioning skill plays an essential role in the learning. Exceptional learning is characterized by good questions, especially from large groups of children. Such categories of can stimulate children's curiosity, imagination and motivation to acquire new knowledge.

Questioning skills are a way of delivering a lesson using a two-way interaction technique, namely from the teacher to the student and vice versa in order to obtain certainty answers through verbal answers (Abimayu, 2007). Questions can challenge students to think, help them clarify concepts and problems related to learning. It also shows the critical power of the child. According to Fakhruddin (2009), questioning is a process of constructing the mind and heart to determine intelligent solutions that can be actualized for the prosperity and benefit of all people.

Learning cannot be separated from the question and answer activities, between students and teachers. The skill of questioning is one of the important scientific dexterity. In the educational process in class, students are required to possess the required ability to ask in order to develop their creativity, and curiosity, as well as to form questions, and critical thoughts needed to live a smart and prolonged academic life.
Pierce (1978) explains that in the learning process, questions are used by the teacher to encourage, guide and assess students thinking skills. For students, the questioning activity is an essential part in conducting discovery-based learning (inquiry) which involves searching for information, confirming what has been studied and directing attention to unknown perspectives.

Furthermore, Robinson (1950) stated this as a twoperson situations in which an individual helps the client to adjust to himself and to his environment. Rogers (1955), described ounseling as a series of direct contacts with the students which aim to offer him assistance in changing his attitudes and behavior.

The definition of counseling according to the experts above, describes this technique as: 1) a process of assistance that takes place in a situation between two students, 2) a service that is professional, 3) directed at changing attitudes and behavior. Sukmadinata (2003) explains that counseling is focused on the client's problems and needs.He further beamed that good counseling is what results from the client's own decisions and should be based on careful predictions from counselors.

In providing counseling services, counselors are expected to work in accordance to its vision and mission, such as the realization of the development of students 
independence optimally in accordance with the nature of humanity as servants of God Almighty. Guidance and counseling service used to realize this goal, utilizes content mastering services.

Prayitno (2017) explained the understanding of content mastery service is that of assistance to students (individually or in groups) in a bid to help them master certain skills or competencies through learning activities. Ability or competition that is learned is a unit of content which contains facts and data, concepts, processes, laws and rules, values, perceptions, affections, attitudes, actions and skills problems students ask in the classical learning process.

According to observations on research conducted by Yunus, Marli and Kresnadi (2013), students learning skills in Indonesian Language subjects are very low, owing to the fact that teachers tend to educate students with only the subject matter. Furthermore, from research observations conducted by Nainggolan, Asran and Kresnadi (2015) illustrated that students rarely ask teachers questions, in Mathematics because they are less skilled in craving questions. The problem with getting the wrong handler is that it will hamper the students education process.

\section{METHODOLOGY}

This research adopted the Research and Development (R and D) (Borg and Gall, 1989) methodology. This R and $\mathrm{D}$ approach is a research process used to develop and validate products (Borg and Gall, 1989). Yusuf (2013) explained that the development research activities were carried out with the intention (1) to develop new products, and (2) to find and create new knowledge about the model, including things that were widely discussed.

This researcher uses the development pattern of ADDIE (Analysis, Design, Development, Implementation, and Evaluation) developed by Mollenda (2003) in figure I.

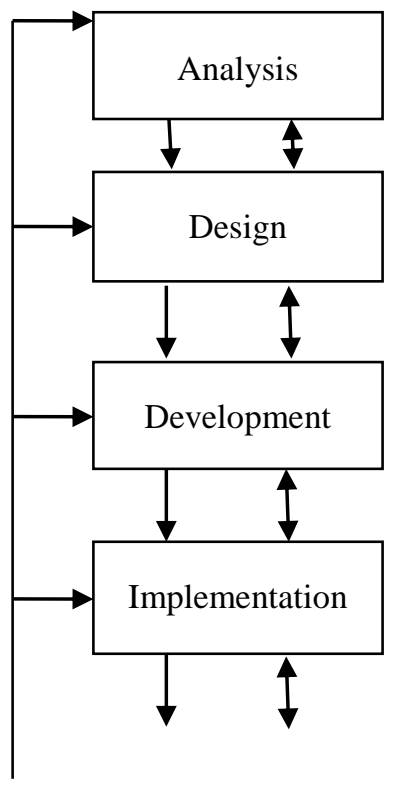

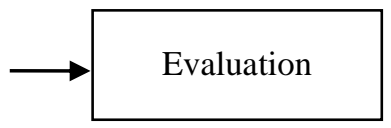

Figure I. The flow of developing the ADDIE pattern

Model development activities in the form of guidebooks and companion books were carried out at the feasibility test stage by 5 experts, the wearability test was by 2 guidance and counseling teachers, and the effectiveness test by 40 students and focus group discussion (FGD).

Data was collected using the Likert scale, questionnaire, and FGD sheet. The collected data is then processed descriptively to describe the characteristics of the score distribution of each respondent by specifying the product test results. In addition, researchers also used non-parametric statistics using Concordance Kendall's W Test and Wilcoxon Signed Rank Test.

\section{RESULT AND DISCUSSION}

\subsection{Result}

Before the presentation of the study, guidance and counseling services were used to enhance students questioning skills, such as their namely content mastery services. Based on the results of the study, it is revealed that using the trial feasibility study at the development stage, experts on the content mastery service model tend to improve the skills of students questioning ability with an overall average value of 101.3 , which means it is in a "very high category" and feasible to be implemented in the State Aliyah Madrasah in Padang City after being refined in accordance with the input from the expert.

Furthermore, based on the coefficient concordance of Kendall's test on the final assessment, the chi-square count was 42,249 . Thus, it can be said that there is an alignment of assessments of the five experts on the research model. In the implementation phase carried out by the Counselor, the results of the wearability test was found to be in the "very high category" with a percentage score of $61.5 \%$. Thus the model that is prepared in the form of a guidebook and companion book can be used by the Counselor at a school. Then, through Concordance Kendall's W Test, a chi-square count of 27,686 was obtained. It can be concluded that both Counselors had a suitable assessment result regarding the model.

The effectiveness test at the evaluation stage obtained the overall results of the pretest score of 67.3 and the posttest value of 99.95. However, based on the Wilcoxon Signed Rank Test, the significance between the pretest and posttest was found to be 0,000 . This means that there is a significant increase before and after the treatment of content mastery service models as described which is used to ameliorate students questioning skills in classical learning.

The results obtained by implementing the content mastery service model and in enhancing students questioning skills, also provide opportunities for students 
to be committed in participating in all subjects. The benefits of increasing this questioning skill can be felt in all learning processes.

\subsection{Discussion}

Certain factors influence students' academic questioning abilities. Students low questioning skills if left alone will have an adverse effect on their and academic achievement in school. Model development in this study resulted in a prototype of content mastery service model used to improve students questioning abilities on classical learning by Counselors in providing guidance and counseling services.

\subsubsection{The Level of the Feasibility of the Model}

The development of this content mastery service model can be conducted by guidance and counseling teachers/counselors to order to enhance students skills, because this service is intended to train people in various aspects. Content mastery services are assistance services for individuals (individually or in groups) to master special learning abilities.

From the results presented in the development stage, the model in the form of a compiled guidebook is considered very feasible in content by experts. Assessment of aspects of appearance, terms of reference, objectives, indicators, steps to implement and use of language from the service model of mastering content in the form of guidebooks and accompanying companion books have been interesting. Then the aspects of the implementation steps of the model developed can be used by Counselors.

Sanjaya (2011) argues, that the questioning skills have a positive impact on the learning process. It can be concluded that guidance and counseling teachers can utilize the content mastery service model to enhance students questioning skills. Halidjah (2012) describes questioning abilities as one of the language skills besides listening, reading and writing. Naturally, the acquisition of these talents needs to be built through active speaking and listening.

\subsubsection{The Level of Usage of the Model}

The research findings, in order to find out the level of usage of the model in the form of guide and companion books, illustrates that the content mastery service model can be used to enhance students skills during classical learning, with a very high category level of guidance and counseling teachers in carrying out these services. The explanation above is supported by an assessment of product wear with a percentage of $61.5 \%$. It can be interpreted that the guidance and counseling teacher can practice the content mastery service model as explained in guidebooks.

The use of this model will direct students to improve their questioning skills in the learning process, so that content mastering services focus more on students ability to master certain skills, such as their questioning abilities. Mills (1977) explained that learning would be effective if it was done using the principle of learning and by practicing. Thus, the content mastery service model which can be used to improve students questioning skills is arranged in the form of guidebooks and companion books.

\subsubsection{Test the Effectiveness of the Model}

Based on the results of the statistical effectiveness using the Wilcoxon Signed Rank Test, it was found that the significance value before (pretest) and after (posttest) given the content mastery service model to enhance students questioning skills was 0,000 . This shows that there is a significant increase in the ability of students to ask the right questions after being given a content mastery service model by the counselor.

Prayitno (2017) explained that content mastery services are assistance services given to individuals (individually or in groups) to master certain learning abilities. The skill learnt is a unit of content that contains facts and data, concepts, processes, laws and rules, values, perceptions, affections, attitudes and actions related to it. Meanwhile, Goetz (1984) in his research stated, that exercises carried out repeatedly will have a very large influence on the ability of skills, as well as the skills demanded by students in the classical learning process.

According to Corr and Perkins (2006), "the messages conveyed by communicators will be received by each communicant according to their own decisions." This usually starts from choosing, interpreting and even remembering it. A result of this, it can be said that the increase in students questioning skills is very important to be mastered by students in order to be able to provide a response in accordance with the stimulus given by the teacher in the learning process.

\section{CONCLUSIONS}

Based on the results of the development and discussion it can be concluded that the content mastery service model which can be used to enhance students questioning skills in classical learning is in the "very feasible category." This is that the model that is prepared in the form of a guidebook and accompanying book can be used by the guidance and counseling teacher to provide educational services to students. The content mastery service model used to enhance students questioning skills can be used as an alternative treatment to make students perform better academically. Furthermore, the effectiveness the test conducted by the Counselor in applying this content mastery service model concluded that there was a significant increase in scores before and after the use of this technique.

Based on the above conclusions, suggestions can be given to Counselors in order to utilize this model to improve students questioning skills in classical learning. 
The next researcher can develop this model in a wider scope.

The guidance and counseling teacher is tasked with guiding and counseling students to improve their quality and expertise, personality, social and professional learning abilities. The high touch that is not answered is the authority of the guidance and counseling teacher such as understanding of students, tenderness and compassion and exemplary, in order to be able to practice the content mastery service model. The model is carried out to enhance students ability to succeed in school programs and activities in education.

\section{REFERENCES}

Abimanyu, S., 2007. Strategi pembelajaran. Jakarta: Depdiknas.

Borg, W. R., and Gall, M. D. 1983. Educational research: An introduction. New York: Longman Inc.

Corr, P. J., and Perkins, A. M. 2006. The role of theory in the psychophysiology of personality: from Ivan Pavlov to Jeffrey Gray. International Journal of Psychophysiology, 62(3), 367-376.

Fakhruddin, A. U. 2009. Menjadi guru favorit. Jogyakarta: Diva Press.

Goetz, P. W. 1984. The new encyclopedi britanica. Vol. $10,15^{\text {th }}$. Ed. Chicago: William Benton Publisher.

Halidjah, S. 2012. Evaluasi keterampilan berbicara dalam pembelajaran bahasa indonesia. Jurnal Visi Ilmu Pendidikan, 2(1).

Pierce, C. M. 1978. Television and education, Vol. 44. Sage Publications, Inc.

Robinson, F. P. 1950. Principles and procedures in student counseling, Psycnet.apa.org.

Prayitno. 2017. Konseling yang berhasil. Jakarta: Ghalia Press.

Rogers, C. S. 1958. A process conception of psychotherapy. American Pcsychologist, 13(4), 142.

Sukmadinata, N. S. 2003. Landasan psikologi proses pendidikan. Bandung: Remaja Rosdakarya.

Yunus, M., Marli, S., and Kresnadi, H. 2013. Peningkatan keterampilan siswa bertanya dengan menggunakan media audio pada pembelajaran bahasa indonesia, Jurnal Pendidikan dan Pembelajaran, 2(4).

Mills, H. R., 1977. Teaching and Training. London: The Macmillan Press, Ltd.

Nainggolan, P. H., Asran, M. and Kresnadi, H. 2015. Peningkatan hasil belajar siswa dalam pembelajaran matematika menggunakan teknik jarimatika di sekolah dasar negeri, Jurnal Pendidikan dan Pembelajaran, 4(12).

Yusuf, A. M. 2013. Metodologi penelitian: Kuantitatif, kualitatif dan penelitian pengembangan.
Molenda, M. 2003. In search of the elusive ADDIE model. Performance improvement, 42(5), 34-36. 